This item was submitted to Loughborough's Research Repository by the author.

Items in Figshare are protected by copyright, with all rights reserved, unless otherwise indicated.

\title{
Interpreting social identity in online brand communities: Considering posters and lurkers
}

PLEASE CITE THE PUBLISHED VERSION

http://dx.doi.org/10.1002/mar.20995

PUBLISHER

(c) Wiley

VERSION

AM (Accepted Manuscript)

\section{PUBLISHER STATEMENT}

This work is made available according to the conditions of the Creative Commons Attribution-NonCommercialNoDerivatives 4.0 International (CC BY-NC-ND 4.0) licence. Full details of this licence are available at: https://creativecommons.org/licenses/by-nc-nd/4.0/

\section{LICENCE}

CC BY-NC-ND 4.0

\section{REPOSITORY RECORD}

Mousavi, Sahar, Stuart Roper, and Kathy Keeling. 2019. "Interpreting Social Identity in Online Brand Communities: Considering Posters and Lurkers”. figshare. https://hdl.handle.net/2134/24697. 
Interpreting Social Identity in Online Brand Communities: Considering Posters and Lurkers

\author{
Sahar Mousavi* \\ Loughborough School of Business and Economics, Loughborough University, UK \\ S.mousavi@lboro.ac.uk
}

\title{
Stuart Roper
}

Bradford University School of Management, University of Bradford, Bradford, UK s.roper@bradford.ac.uk

\section{Kathy Keeling}

Alliance Manchester Business School, University of Manchester, Manchester, UK Kathy.keeling@manchester.ac.uk

* Corresponding author 


\title{
Interpreting Social Identity in Online Brand Communities: Considering Posters and Lurkers
}

\begin{abstract}
This study investigates the psychological effects of social identity on both posters and lurkers in online brand communities (OBCs). The results reveal the intermediate mechanisms mediating and moderating members' social identity effects on members’ brand commitment, leading to positive word-of-mouth and their resistance to negative information about the brand. This article treats social identity as a multi-dimensional construct. Differences amongst posters and lurkers on the relationships between the cognitive, affective and evaluative components of social identity are investigated along with their positive effect on brand commitment and behavioral consequences. Using a sample of 752 OBC members, both posters and lurkers emerge as valuable members and equally likely to derive social identity from their membership of an OBC. However, there are counter intuitive results for relationships within the research model between active and passive members of OBCs. These results offer implications for theory and can help managers to be better interactive marketers.
\end{abstract}

Keywords: Online brand communities, social identity, brand commitment, posters, lurkers. 


\section{Interpreting Social Identity in Online Brand Communities: Considering Posters and Lurkers}

\section{Introduction}

The Internet and electronic technology have moved to the core of the marketing function (Ratchford, 2015) and the growing influence of online marketing communications has been recognized (Ashley \& Tuten, 2015; Shankar \& Batra, 2009). The sophisticated information and communication technologies that have evolved, aligned with the rise of the Internet and Web 2.0, have served as platforms to facilitate the interaction with and among customers and brands, leading to the formation of online brand communities (OBCs) (Brodie et al., 2013; Zhou et al., 2013). An OBC is an aggregation of individuals who interact online, focusing on a particular brand as their shared interest. A rich stream of research examines interactive customer-brand relationships in specific social media settings such as OBCs (Hollebeek, Glynn, \& Brodie, 2014; Steinmann, Mau, \& Schramm-Klein, 2015). This is important because what customers know and think consciously and unconsciously about a brand affects their attitudes and behaviors toward that brand and ultimately brand success (Koll, von Wallpach, \& Kreuzer, 2010). Researchers and practitioners therefore have an interest in understanding the psychological effects of membership of OBCs on customers' behavior.

Offline brand communities are geographically as well as time constrained and the main mode of interaction is face-to-face. However, the OBC operates differently allowing members the opportunity to reveal little of their identity and only passively engage with the community (Wirtz et al., 2013). Research on OBCs has typically concentrated, perhaps understandably, on the active participation of community members and its effects on customer-brand relationships and consumer brand evaluations (e.g., Adjei, Noble, \& Noble, 2010; Algesheimer, Dholakia, \& Herrmann, 2005; Brodie et al., 2013; Steinmann, Mau, \& Schramm-Klein, 2015). However, active members, known as 'posters', do not represent the 
whole population of OBC members. Passive, non-interactive members, often termed 'lurkers', make up the majority of members in online communities (Nonnecke \& Preece, 2000; Schlosser, 2005; Schneider, Von Krogh, \& JäGer, 2013; Walker, Redmond, \& Lengyel, 2013), and represent up to 90\% of members (Nielsen, 2006). Brand community members' passive participation, referred to as 'lurking', or 'consumptive forms of community participation’ (Hartmann, Wiertz, \& Arnould, 2015, p. 319) has been neglected to date and is poorly understood in the OBCs literature. If companies/researchers only gather data from active users, this could have biased the research into OBCs to date. Does this mean that an OBC has no effect or impact upon those who do not post? Receiving comments from others and observing what others do (i.e., passive or consumptive participation) are ordinary elements of participation and can create value for the brand (Hartmann, Wiertz, \& Arnould, 2015). As such, this resembles vicarious learning, a normative and powerful means of sense making (Bandura, 1971; 1986), and so, lurking might also be deemed normative and a powerful way of gaining knowledge about the community and the brand, affecting attitudes and future behavior. Given that lurkers compose the majority of the OBCs audience, then although the drivers and motivations of active members in OBCs have received ample research, more work is necessary to understand passive participation, lurking, and its consequences for OBC success (Stokburger-Sauer \& Wiertz, 2015; Walker, Redmond, \& Lengyel, 2013). This paper therefore seeks to develop a better understanding of passive participation in OBCs and suggests that 'productive social roles' (activity) (Hartmann, Wiertz, \& Arnould, 2015, p. 319) are not the most important thing for an OBC; passive social roles (visiting) may be equally important.

The paper draws on social identity theory to reach a better understanding of lurkers, comparing them with posters and investigates the consequences of their participation in OBCs on their commitment towards the brand. Social identity captures the key aspects of the 
individual's identification with the community, demonstrated when members categorize themselves as part of the community, valuing this identity positively, and using it to form a shared consciousness (Dholakia et al., 2009). People often identify socially with groups even when they have no contact with specific members of that group (Turner, 1982; Ahearne, Bhattacharya, \& Gruen, 2005). Relevant aspects of Social Cognitive Theory (Bandura, 1971; 1986) also help to provide an explanation of how social identities develop without the need for active social interaction. Therefore, in the context of this research, although lurkers do not actively participate in the community, it is reasonable to say that both posters and lurkers feel the sense of social identity in OBCs. However, there are still theoretical and practical blind spots related to active and passive behaviors in OBCs (Pagani, Hofacker, \& Goldsmith, 2011).

To summarize, this paper seeks to address these gaps by distinguishing between the cognitive, affective and evaluative components of social identity in OBCs for both posters and lurkers and shows how these components stimulate brand commitment, positive word-ofmouth and resistance to negative information. This will provide management insight into OBC’s in their entirety.

The remainder of the paper proceeds as follows. First, there is a review of theoretical underpinnings of our research and hypotheses are developed. Next, the research method is developed followed by the presentation of the data analysis procedures and results. Finally, the paper concludes with a discussion providing theoretical and managerial implications followed by limitations and suggestions for future research. 


\section{THEORETICAL FOUNDATION AND CONCEPTUAL FRAMEWORK}

\section{Social Identity in Online Brand Communities}

Brand communities are social organizations wherein members voluntarily join and retain their membership while deriving benefits from participating in the community (Kim et al., 2008). Brands and brand consumption can build a foundation for the classification of individuals into social categories (Stokburger-Sauer, 2010), such as OBCs. For Muniz and O’Guinn (2001, p 412), “Community is a core construct in social thought”, thus establishing the importance of the social identity perspective in research into OBCs. The presence of a social identity amongst members is an essential condition for considering a social group to be a community (Muniz \& O’Guinn, 2001). According to social identity theory individuals enhance their self-esteem by associating with individuals and groups that reflect their desired identity (Tajfel \& Turner, 1979). Social identity expresses the strength of the social relationships that a customer has with other members of the community through a shared collective identity (Dholakia et al., 2009). Thus, in OBCs, individuals can develop their identities by participating in these communities, adopting their norms and values and by devoting their efforts to strengthening these communities (Algesheimer, Dholakia, \& Herrmann, 2005; Johnson \& Lowe, 2015). The strength of an individual's social identification with a brand community is an essential driver of participation and the member's relationship with the community and the brand (c.f., Bagozzi \& Dholakia, 2006; Carlson, Suter, \& Brown, 2008; Zhou et al., 2012).

Considering the usefulness of OBCs as marketing instruments that build brands and increase customer loyalty (Hartmann, Wiertz, \& Arnould, 2015), a more detailed and comprehensive understanding of how customers' social identity can be engendered in OBCs is valuable. Building on the insights of Tajfel's (1978) argument that a person achieves a social identity through self-awareness of one's membership in a group and the emotional and 
evaluative significance of this membership, three empirically distinct components of social identity have been proposed (Ellemers, Kortekaas, \& Ouwerkerk, 1999; Bergami \& Bagozzi 2000): a cognitive component, an emotional component, and an evaluative component.

The cognitive aspect of social identity includes judgments about similarities with other members of the community and dissimilarities with non-members, which captures the consciousness-of-kind aspect of social groups (Tsai \& Bagozzi, 2014; Zaglia, 2013). Such cognition is perceived as overlap between one's own self-concept and the identity of the community (Bergami \& Bagozzi, 2000). The emotional component of social identity takes this process a step further, into feelings of attachment to the community and is referred to as the affective commitment to the community (Tsai \& Bagozzi, 2014). Finally, the evaluative component of social identity postulates the evaluations of self-worth derived from membership. Some researchers refer to this component as group-based self-esteem (Bagozzi \& Dholakia, 2002) or collective self-esteem (Luhtanen \& Crocker, 1992).

In online community studies to date social identity has been mainly considered as a second-order factor of its three components (e.g. Bagozzi \& Dholakia, 2002; 2006; Eisenbeiss et al., 2012). This means previous researchers focused specifically on the case "where overall social identity has already formed and exists in the three components" (Tsai \& Bagozzi, 2014, p.148). However, prior research suggests that the cognitive component develops early and then influences the affective and evaluative components of social identity (Bergami \& Bagozzi, 2000; Ellemers, Kortekaas, \& Ouwerkerk, 1999). An individual may classify himself or herself as belonging to one group and not another (cognitive dimension), and evaluate the in-group in a positive way, but still remain quite emotionally unattached to the group (Jackson \& Smith, 1999). Moreover, recent literature signifies the importance of conceptualizing and studying the different components of social identity separately (Wolter \& Cronin Jr., 2015) to clarify which dimension is driving outcomes and which dimension is 
more important in predicting which outcome (Lam, 2012). Therefore, it is necessary, rational and informative to distinguish between these different dimensions, examine relationships amongst them, and determine the mechanisms through which they influence customers' commitment to the brand in OBCs.

\section{Relationships between Social Identity and the Brand in OBCs}

Identification with an organization is influenced by the individual's perceptions of organizational prestige and distinctiveness (Ashforth, Harrison, \& Corley, 2008; Mael \& Ashforth, 1992). Bhattacharya and Sen (2003) argue that the more prestigious and distinctive are consumers' perceptions of a company's identity, the more attractive that identity is to them, leading to a higher level of consumer-company identification. Individuals try to keep a positive social identity by associating with a prestigious company (Ahearne, Bhattacharya, \& Gruen, 2005) since such association delivers them social opportunities (Brown, 1969) and reinforces social prestige (Ashforth \& Mael, 1989; Cheney, 1983). Overall, support has been found for relationships between the prestige and attractiveness of organizations and identification in a number of contexts, including employee-company identification (Smidts et al., 2001), customer-company identification (Ahearne, Bhattacharya, \& Gruen, 2005; CurrásPérez, Bigné-Alcañiz, \& Alvarado-Herrera, 2009), and customer-brand identification (Elbedweihy et al., 2016; Kuenzel \& Vaux Halliday, 2008; Stokburger-Sauer, Ratneshwar, \& Sen, 2012). When a customer sees the external image of a brand as distinctive and prestigious, the customer's identification with that brand strengthens. Consequently, since an OBC is centered on one specific brand, it can be proposed that perceived brand prestige and brand distinctiveness are positively related to the extent the individual perceives overlap between their own identity and the community identity (i.e., their self-categorization). Members of a community attempt to derive a positive social identity as a consequence of their membership 
(Tajfel \& Turner, 1979; 2004). Brand prestige and distinctiveness as two symbolic and psychological antecedents of members' identification with the community (Lam, 2012) correspond to the needs of self-enhancement and self-distinctiveness of community members (Bhattacharya and Sen, 2003). Membership of an online community related to a prestigious and distinctive brand provides individuals with enhancement opportunities for their sense of self and communication of this to others (Bhattacharya, Rao, \& Glynn, 1995). People enhance a positive social identity, particularly self-categorization, through identifying themselves with prestigious and distinctive brand communities. All the above effects should strengthen members' self-categorization. We therefore hypothesize:

H1: Members' perception of brand prestige influences their self-categorization positively.

H2: Members' perception of brand distinctiveness influences their self-categorization positively.

Considering the three components of social identity, the cognitive component (selfcategorization) is the essential first step of identifying with a group (Van Dick, 2001). Once an individual perceives him or herself as a member of a social group, the other components come into play (Van Dick et al., 2004) and so the individual feels affective ties (strong or weak) towards this group (affective component) and positively or negatively evaluates the associations with his- or her membership in the group (evaluative component).

Community-based self-esteem, which is the evaluative component of social identity, is a type of group or collective self-esteem defined as evaluations of self-worth deriving from one's membership in the community (Bergami \& Bagozzi, 2000). This resonates with Tajfel's (1981) opinion that social identity involves an evaluative component, as “...the notion of the group or of one's membership in it may have a positive or negative value 
connotation” (p, 229). Evaluative social identity relates to self-esteem (Brown et al., 1986). Hence, perceptions of social identity influence an individual's sense of self-worth (Blanton \& Christie, 2003). To the degree that identification with a community is a salient basis of one’s self-evaluation (Bergami \& Bagozzi, 2000), the need to maintain or enhance their community-based self-esteem motivates membership. Therefore, following Bergami and Bagozzi (2000) study, it is hypothesized that an individual's self-categorization with an OBC enhances their community-based self-esteem.

H3: Members' self-categorization influences their community-based self-esteem positively.

Previous research on identification, based on a brand or a company, is almost completely set within the social identity perspective (Lam, 2012; Wolter \& Cronin Jr., 2015). Consumers' identification with a company/brand is an intense, significant psychological link (Currás-Pérez, 2009), that involves the consumer's desire to establish a closer, long-term relationship with the company/brand (Bhattacharya \& Sen, 2003; Marin \& Ruiz, 2007). Furthermore, self-congruity theory suggests that an individual forms a stronger bond with a brand community when the community and self-identities converge (Aaker, 1999; Burmann \& Zeplin, 2005; Sirgy, 1982). A consumer who identifies with a company is likely to have positive thoughts and feelings towards it (Einwiller et al., 2006). Extant research in organizational studies indicates that identification with a company results in a commitment to it (Bergami \& Bagozzi, 2000; Brown et al., 2005). Thus, this paper supports the Meyer and Allen (1997) contention that community identification results in a psychological bond describing a member's relationship with the community. Socio-emotional resources that members accumulate through experiential routes of interactions in online communities positively influence their reciprocating behavior and so their commitment to the community (Chan \& Li, 2010). When members of an OBC perceive an appreciable overlap between their 
ideas about who they are as a person (i.e., their self-identity) and what the community is and stands for (i.e., the community's identity), the greater are their feelings of attachment and belongingness to that community (i.e., affective commitment towards the community).

H4: Members' self-categorization influences their community affective commitment positively.

People with perceptions of high collective self-esteem pursue enhancement for their ingroup and through this reinforce their collective self-esteem (Bergami \& Bagozzi, 2000). Consistent with reciprocal action theory, a partner in an exchange relationship reciprocates actions taken by another party to avoid feelings of guilt for disobeying the norm of reciprocity (Li \& Dant, 1997). Customers build up a strong sense of commitment to an organization to return the firm's active relationship building efforts (Wulf, OdekerkenSchröder, \& Iacobucci, 2001). Considering socio-emotional argument, organizational identity literature suggests that fulfilling individuals needs for esteem and approval leads to the development of a strong affective commitment to the organization (Lee \& Peccei, 2007). The satisfaction of important higher-order needs is experienced as psychologically fulfilling by employees and it is indeed these psychologically rewarding experiences that are at the foundation of the development of affective commitment (Meyer \& Allen, 1991; 1997). Similarly, OBC members who perceive self-enhancement from their community membership respond by forming feelings of belonging and connection to the community and so promoting their affective commitment to the community.

H5: Members' community-based self-esteem influences their community affective commitment positively.

Social identity perspective, developed in social psychology, signifies how membership in a group provokes individuals to act in favor of that group (Hornsey, 2008). This 
perspective predicts that individuals who are committed to an organization commit themselves to actions that support the organization (Dutton \& Dukerich, 1991; Bergami \& Bagozzi, 2000). When an individual is committed to a group, such as an online community, they become vested in the successes and failures of it (Ashforth \& Mael, 1989; Kim et al., 2008). In general, the more an individual feels an affective bond towards the group the more positively he or she appraises the group and the more he or she will act on behalf of the group (Van Dick et al., 2004). This infers that individuals committed to an OBC develop a positive attitude and behavior towards the brand itself and so increase their affective brand commitment.

Affective brand commitment lies at the heart of the customer-brand relationship (Fullerton, 2005). It refers to the degree to which an individual is psychologically bonded to the brand out of desire (Bansal, Irving, \& Taylor, 2004; Gruen, Summers, \& Acito, 2000) and is related to 'wanting' to maintain a relationship (Lariviere et al., 2014). Affective brand commitment is a more emotional factor that grows through the degree of reciprocity or personal involvement that a customer has with a brand (Gustafsson, Johnson, \& Roos, 2005). The extent of $\mathrm{OBC}$ member attachment and belonging to the community corresponds with attitude towards the brand around which the community is developed. Thus, the degree of brand community affective commitment affects brand affective commitment as a function of the degree of emotional involvement with the community that is around the specific brand.

H6: Members' community affective commitment influences their affective brand commitment positively.

Hagel and Armstrong (1997) argue that effective communities generate higher customer loyalty behaviors and positive economic returns. OBCs are marketing instruments that support brands and increase customer loyalty and commitment (Hartmann, Wiertz, \& Arnould, 2015). Three strands of literature suggest that self-identification with a community 
will lessen acceptance and the spreading of negative information. First, are the implicit social 'rules' or 'relational schema' for group behavior, these represent expectations of the nature of behavior within relationships; amongst these are positive regard (Mottet \& Richmond, 1998) and refraining from criticism (Argyle, 1992). Second are the affective and cognitive results of forming social identities on how negative information is considered. Strong affective bonds have been shown to have a positive impact on forgiveness based on a desire to continue the relationship (Eisingerich et al., 2011; Finkel et al., 2002). Cognitively, individuals tend to reject negative information that might threaten a valued social identity that is part of selfimage, indeed, some theorists believe that self-protecting cognitive biases are pervasive, strong and have an adaptive, evolutionary function (Alicke \& Sedikides, 2011).

Previous research shows that it takes a strong relationship for consumers to exhibit resistance to negative information (Aaker, Fournier, \& Brasel, 2004; Ahluwalia, Burnkrant, \& Unnava, 2000; Dimitriadis \& Papista, 2010). Therefore, it is expected that individuals who have a stronger affective commitment toward a brand may have greater resistance to negative information, defined as the extent to which individuals do not allow negative information to diminish their general view of the brand (Eisingerich et al., 2011).

Moreover, in the context of brand communities, previous research has found that members of the community often reveal behaviors and intentions that are consistent with determined group norms, such as word-of-mouth promotion of the brand, and having a preference for the brand (Algesheimer, Dholakia, \& Herrmann, 2005; Kim et al., 2008). Therefore, it is hypothesized that:

H7: Members' affective brand commitment influences their positive word-of-mouth positively.

H8: Members' affective brand commitment influences their resistance to negative information positively. 
There are also some implications for other relationships flowing from these hypotheses. According to the prosocial behavior literature, affect such as emotional concerns, plays a crucial role in persuading individuals to participate in behaviors that go above and beyond the call of duty (e.g., Eisenberg \& Miller, 1987; Lam, 2012). "Emotion is a central aspect of many marketing relationships (Bagozzi, 1995, p. 274). Therefore, considering the social identity dimensions, it is expected that the affective facet will be more predictive of customers' extra-role behaviors and commitment to the brand itself. We argue that selfcategorization and community-based self-esteem provide a basis for members' attitude towards the brand but that community affective commitment supplies the motivational force (Bergami \& Bagozzi, 2000). Of the three components of social identity, Cater and Zabkar (2009) find community affective commitment the only major influence on customer loyalty. The model (figure 1) shows community affective commitment as the direct determinant of affective brand commitment. Thus, community affective commitment mediates the relationships between cognitive and evaluative components of social identity (i.e., selfcategorization and community-based self-esteem) and members' affective brand commitment. Subsequently, there are no direct relationships between affective brand commitment and selfcategorization or community-based self-esteem in this model.

H9a: Members' community affective commitment mediates the positive effect of selfcategorization on affective brand commitment.

H9b: Members' community affective commitment mediates the positive effect of community-based self-esteem on affective brand commitment.

[Insert Figure 1 about here] 


\section{Moderating Effects of Members’ Participation Type}

From managerial and theoretical standpoints, it is essential to consider what type of customer accentuates the online brand community's influence on its members. We consider the members' participation type in an OBC. An individual participation in online communities can be divided into two main types: posting (active or interactive members) and lurking (passive or non-interactive members) (Preece, Nonnecke, \& Andrews, 2004; Ridings, Gefen, \& Arinze, 2006). Studies comparing posters and lurkers are infrequent, so there is insufficient knowledge about poster-lurker differences in social identity formation and effects in online communities. However, studies in two areas, social identity formation and motivations for sharing knowledge in online communities, both support the premise that social identity drivers, formation and consequences may vary between the two groups.

In social identity theory, previous studies posit two distinct paths that can result in social identity formation (deductive and inductive) (Postmes, Haslam, \& Swaab, 2005). The inductive route finds its basis in interactive participation in groups (Postmes, et al., 2005), thus it is a bottom-up process. Cheng and Guo (2015) discuss these two routes with reference to online communities and links the inductive route to poster activity and shows that interactive behaviors can lead to the formation of social identity in online communities. They consider that, for online communities, “because of the lack of physical cues, members' behavioral involvement and social relations play vital roles in .... perceiving their own embeddedness in the community” (p. 238). Jans, Postmes, and Van der Zee (2012) find that, in heterogeneous groups, inductive social identity formation can result in higher identification than deductive social identity formation.

Postmes et al. (2005) describe the deductive route a top-down process of selfcategorization, formed based on a response to the perceptions of shared characteristics within the group (Postmes et al., 2005). Thus, it does not necessarily require active social interaction. 
Social Cognitive Theory (SCT) (Bandura, 1971; 1986) provides an explanation of how aspects of social identity, such as self-categorization are acquired by lurkers without the need for active social interaction. Vicarious learning (Bandura, 1971; 1986) posits that humans have a basic but powerful symbolizing capability that allows adaptation to and sense making of environments, and that this knowledge can be learnt vicariously by observation rather than directly. Indeed, vicarious learning is an important advantage as it decreases the need for the more costly 'trial and error' learning (Bandura, 1971; 1986). Thus, SCT predicts that many people would show 'lurking' behavior, especially in environments where others are not necessarily known to them. The SCT perspective is that, contrary to being a non-productive, non-participative behavior, this is a positive activity and a powerful means for acquiring knowledge and guiding future behavior. As such, it is argued that it is also a powerful means for deductive social identity formation. Cheng and Guo (2015) also implicitly link lurking behavior to the deductive route but do not test this idea empirically. They do, however, argue that posters will form a stronger social identity than lurkers as the former will have more experience of involvement in the group tasks and consequently a greater emotional attachment to the group. Their study, however, is not of brand communities. Brand community environments may promote vicarious learning more than others. Breitsohl, Kunz and Dowell (2015) posit there is more content on OBCs than in other types of online communities. This suggests that social identity, including self-categorization may be readily formed in OBCs without interaction as information rich environments allow vicarious learning to flourish.

The second line of support for differences between posters and lurkers in the effects of social identity, are studies on motivations for knowledge sharing in online communities. These provide evidence that social identity motivations for posting vary between posters and lurkers (e.g., Lai \& Chen, 2014). Suh (2013) demonstrates a link between the degree of 
difference between the virtual and real self and the quality and quantity of sharing knowledge amongst posters. Preece, Nonnecke, and Andrews (2004) describe reasons for not posting, rather than motivations to post, that might affect lurkers. Amongst these are potential social identity factors that would be predicted by SCT, such as needing to understand the community and the social norms around posting as well as being worried about others reaction to the quality of their contribution. Significantly, in one of few studies of both posters and lurkers, Lai and Chen (2014) find lurkers motivated by intra-community factors, which supports the premise informed by SCT. This work is supported by the arguments for the deductive route to self-categorization, that direct social interaction is not necessary for social identity formation and lurkers might form social identity by the deductive route, that is, from the characteristics and content of the brand community website.

Thus, for OBCs, it is believed that both posters and lurkers may form social identity by the deductive route. Nevertheless, motivations differ between the two groups. For posters, social identity can also take place by the inductive route (Cheng \& Guo, 2015). Current evidence also leads to the conclusion that posters should form a stronger social identity than lurkers (Cheng \& Guo, 2015; Jans, Postmes, \& Van der Zee, 2012) as they generally have more depth of experience due to their social interaction. Consequently, the strength of components of social identity will be higher for posters and because of the differences in motivation; the strength of the paths between the components of social identity and the consequences will differ between the two.

Therefore, moderation effects are hypothesized such that:

H3a: The impact of self-categorization on community-based self-esteem is stronger for posters than for lurkers

H4a: The impact of self-categorization on community affective commitment is stronger for posters than for lurkers 
H5a: The impact of community-based self-esteem on community affective commitment is stronger for posters than for lurkers

H6a: The impact of community affective commitment on affective brand commitment is stronger for posters than for lurkers

H7a: The impact of affective brand commitment on positive WOM is stronger for posters than for lurkers

H8a: The impact of affective brand commitment on resistance to negative information is stronger for posters than for lurkers 


\section{RESEARCH METHODOLOGY}

\section{Sample and Data Collection}

An online survey was developed in order to collect data. The choice of using an online survey is consistent with the context of this study since the population of interest for this research is members of online brand communities who are Internet users, and therefore, using an online survey technique is the most effective technique to reach them successfully. Members of an online panel who self-identified as current members of real OBCs (visited in last three months) served as respondents to this survey. In the introduction of the questionnaire, stated that the survey was about people's participation in online brand communities and their feelings towards the brand around which the community is developed. As in Porter and Donthu (2008), the online survey started with a description and several examples of real OBCs to provide a common understanding of definitions for respondents. Respondents then identified the name and the URL address of a community of which they were a member and would refer to during the survey. To make sure that all respondents understood the meaning of OBCs and met the criteria of the sample definition, they had to answer two screening questions after they self-identified themselves as members of an OBC. 1) Have you visited your chosen online brand community within the last three months? 2) Does your chosen online community center around one specific brand? This strategy provides the opportunity to gather data from different OBCs without limitation to researcher chosen communities, so providing variability in the data to test the proposed model and increase the generalizability of the results. Moreover, it gave the authors the opportunity to gather data from lurkers since due to their defined non-participatory nature, it is difficult to get lurkers to respond to surveys ( Preece, Nonnecke, \& Andrews, 2004).

Within three weeks of the launch of the survey, the link to the online survey was sent to 4,065 panelists and 1,004 of these individuals completed the survey, an absolute response rate 
of $25 \%$. After screening the data 752 usable questionnaires that passed all screening questions remained an effective response rate of $18 \%$. The respondents were US residents, $48 \%$ male, 52\% female, with ages ranging between 18 and over 65. This research defined 'lurkers' as members who do not post or post very infrequently (Nonnecke \& Preece, 2000; Ridings, Gefen, \& Arinze, 2006). Therefore, members who have not posted a comment and/or a question on their chosen community website within the last three months or posted less than once a month were considered as lurkers. The total number of lurkers identified in this study was 415 or $55 \%$ of respondents, and the remainders of respondents (337) were considered posters (45\%). Table 1 shows the profile of both posters and lurkers.

[Insert Table 1 about here]

\section{Construct Measurements}

All items were measured using 9-point Likert scales, anchored by 1 (strongly disagree) to 9 (strongly agree) unless it is specified otherwise. Three items adapted from Baek, Kim and Yu (2010) provided the measure of brand prestige that refers to the relatively high status of product positioning associated with a brand. Brand distinctiveness indicates the perceived uniqueness of a brand's identity in relation to its competitors, measured by adapting three items from Stokburger-Sauer, Ratneshwar and Sen (2012). Two items (one visual) measured self-categorization (cognitive social identity) (Bergami and Bagozzi 2000) as the perceived overlap between an individual's self-concept and the identity of the community. An adapted four-item scale from Bagozzi and Dholakia (2006) and Bateman, Gray and Butler (2011) measured community affective commitment (affective social identity), anchored by 1 (not at 
all) to 9 (very much), as the emotional component of the members' social identity, which reflects the attachment to, or feelings of belongingness with, the brand community. Measures of community-based self-esteem (evaluative social identity) rely on a four-item scale (Bagozzi \& Dholakia, 2006; Luhtanen \& Crocker, 1992) to assess members’ evaluation of self-worth based on belonging to the community. We also adapted items from Meyer and Allen (1997) to measure affective brand commitment as a desire-based attachment to the brand where customers remain with the brand because they want to. To measure Positive WOM, three items were adapted from Zeithaml, Berry, and Parasuraman (1996). Resistance to negative information is the extent to which consumers do not change their general view of the brand despite considering negative information about the brand and measured by adapting 4 items from Eisingerich et al. (2011).

\section{DATA ANALYSIS}

The research model and hypotheses were tested using structural equation modeling (SEM) with AMOS (v22.0) (Byrne, 2013). Following the recommendation of a two-stage analytical procedure (Anderson \& Gerbing, 1988), confirmatory factor analysis was performed using Maximum Likelihood Estimation. This was then followed by path analysis of the structural relationships. Both mediation and moderation analyses were also conducted in AMOS.

\section{Measurement Model}

Data were assessed for the multivariate normality assumption. First, the multivariate outliers were detected by the Mahalanobis distance $\left(D^{2}\right)$ measure, a multivariate assessment of each observation across a set of variables (Hair et al., 2010). The procedure detected 19 cases as outliers. After an analysis of the raw data, it was apparent that these cases were representative 
and not deviant of observations in the population, thus all outlying cases were retained for final analysis (Hair et al., 2014). Second, the distribution of the observed variables showed that the skewness and kurtosis values of most items were below |1|. Highest skewness was |1.56| and highest kurtosis was |3.27|. Since severe non-normality associates with skewness higher than $|2|$ and kurtosis higher than |7| (Boomsma \& Hoogland, 2001; Pagiaslis \& Krontalis, 2014), data were considered suitable for subsequent analyses.

In the confirmatory measurement model all the items load highly on their corresponding constructs $(p<.001)$ (see table 1$)$. Cronbach's alpha level for all constructs is above .84 (table 2), indicating high internal consistency (Nunnally, 1978). Construct reliability of all eight constructs exceeds .85, above the recommended value of .60 (Bagozzi \& Yi, 1988). Average variance extracted (AVE) is above .65 (AVE > .50) for all variables, confirming construct validity (Fornell \& Larcker, 1981). Moreover, there is sufficient discriminant validity as the AVE values for any two constructs exceed the square of the correlation estimate between them (Fornell \& Larcker, 1981) as detailed in table 3. The overall model fit indices $\left(\chi^{2}(296)=947.559, p<.001\right.$; Normed chi-square $\left(\chi^{2} / d f\right)=3.201$, which is less than the cut-off criteria of 5 (Schumacker \& Lomax, 2004); CFI (Comparative Fit Index $)=.97 ;$ NFI $($ Normed Fit Index $)=.96 ;$ IFI $($ Incremental Fit Index $)=.97 ;$ RNFI (Parsimony Normed Fit Index) $=.81$; RMSEA (Root Mean Square Error of Approximation) $=.054$ with the $90 \%$ confidence interval of RMSEA $(\mathrm{LO}=.050, \mathrm{HI}=.058)$ ) are satisfactory (Hair et al., 2010). Generally, these results indicate that the study measurement constructs possess adequate reliability and validity.

CMV: The design of this study contained several procedural remedies to minimize common method variance: avoiding vague, complex, and double-barrelled questions, preventing respondents access to their previous answers, increasing respondents motivation to answer all questions correctly by explaining how much their help was needed, stressing the importance 
of accuracy and conscientiousness, guaranteeing them anonymity and confidentiality, and assuring all of them that there were no 'right' or 'wrong' answers (Podsakoff et al., 2003; 2012). Additionally, we placed demographic information questions between sections of the main questionnaire as a cognitive break. Moreover, neither the Harman's single-factor test (cf. Andersson \& Bateman, 1997) nor a follow-up comparison CFA indicate the presence of a single general factor. For the latter test, loading all 27 items into one confirmatory factor (Podsakoff et al., 2003) resulted in fit statistics $\left(\chi^{2}(324)=9866.339, p<.001\right.$; Normed chisquare $\left(\chi^{2} / d f\right)=30.452 ; \mathrm{CFI}=.56 ; \mathrm{NFI}=.55 ; \mathrm{IFI}=.56 ; \mathrm{RNFI}=.51 ; \mathrm{RMSEA}=.198$ with the $90 \%$ confidence interval of RMSEA $(\mathrm{LO}=.195, \mathrm{HI}=.201)$ ) representing an appreciably worse fit than the study measurement model $\left(\chi^{2}(28)\right.$ for comparison $\left.=8918.78 ; p<.001\right)$. These results support the supposition that common method bias does not present a significant problem in this study.

[Insert Table 2 about here]

[Insert Table 3 about here] 


\section{Structural Model}

The structural model fit statistics indicate a good model fit: $\chi^{2}(315)=1474.690, p<.001$; Normed chi-square $\left(\chi^{2} / d f\right)=4.68$; CFI $=.95 ;$ NFI $=.93 ;$ IFI $=.95 ;$ RNFI $=.84$; RMSEA $=.070$ with the $90 \%$ confidence interval of RMSEA $(\mathrm{LO}=.066, \mathrm{HI}=.074)$.

The data support all the hypothesized relationships in our model (table 4). For H1 and H2, significant associations exist in the data between the positive effects of brand prestige $(\gamma$ $=.32 ; p<.001)$ and brand distinctiveness $(\gamma=.24 ; p<.001)$ on self-categorization, these explain up to $26 \%$ of the variance in the self-categorization construct. Supporting $\mathrm{H} 3$ and H4, self-categorization is a significant predictor of community-based self-esteem $(\beta=.65 ; p$ $<.001$ ), explaining $43 \%$ of the variance in the construct, and community affective commitment $(\beta=.39 ; p<.001)$. Supporting H5, community-based self-esteem is significantly and positively related to community affective commitment $(\beta=.56 ; p<.001)$. The percentage of variance in community affective commitment as explained by its two respective antecedents is $75 \%$. Supporting H6, a positive relationship exists from community affective commitment to affective brand commitment ( $\beta=.78$; $p<.001)$, explaining $61 \%$ of variance in this construct. Finally, supporting $\mathrm{H7}$ and H8, affective brand commitment is a significant driver of positive WOM $(\beta=.58 ; p<.001)$ and resistance to negative information $(\beta=.43 ; p<.001)$ explaining $34 \%$ and $18 \%$ of the variance in them respectively.

[Insert Table 4 about here]

\section{Mediating Effects of Community Affective Commitment}

The mediation hypotheses (H9a and H9b) were tested using the approach advocated by Zhao, Lynch, and Chen (2010). We examined the relationships in the model to determine if 
community affective commitment mediated the relationship between the antecedent variables of self-categorization and community-based self-esteem and the dependent variable, affective brand commitment. The bootstrap confidence intervals of indirect effects were estimated using 10,000 samples and with a bias-corrected confidence level of 95 (Jiménez \& Mendoza, 2013, Slade et al., 2015).

The mediation tests in Table 5 show that affective brand commitment partially mediates, or in other words complementary mediate (Zhao, Lynch, \& Chen, 2010), the impact of Selfcategorization on affective brand commitment (H9a). The indirect path from selfcategorization to affective brand commitment is stronger than the direct one, consistent with mediation (Peltier, Zahay, \& Lehmann, 2013), and both the indirect and direct effects are significant. These results indicate that community affective commitment does mediate the path from Self-categorization to affective brand commitment. However, because the relationship is not that of full mediation, there might be an omitted mediator in the direct path, and so another factor to consider in future analyses (Peltier, Zahay, \& Lehmann, 2013; Zhao, Lynch, \& Chen, 2010).

Table 5 also shows that community affective commitment mediates community-based self-esteem, that is, the latter has an 'indirect-only' effect when analyzing members' commitment towards the brand. The indirect effect of community-based self-esteem on affective brand commitment is larger than the direct effect, consistent with mediation, and the direct effect becomes non-significant when the indirect effect is included in the analysis. This result reveals strong support for our hypothesized relationship (H9b) and means that as members' community-based self-esteem increases, feeling of attachment towards the community is essential to build members' commitment towards the brand. 
[Insert Table 5 about here]

\section{Moderating Effects of Members' Participation Type}

Using multiple sample analyses (Jöreskog \& Sörbom, 1999) we tested the hypotheses for the moderating effects of members participation type for posters and lurkers subsamples and members' gender for male and female subsamples. Running multi-group structural models requires initial tests of measurement invariance through multi-sample confirmatory factor analyses (MCFA) (Byrne \& Watkins, 2003; Cheung, 2008; Hair et al., 2010). The measurement invariance testing process demonstrated that all eight variables in the model met the criteria for configural invariance and full metric invariance (see Appendix A).

Testing the moderating hypotheses (H3a-H8a) entails two separate structural models for the lurkers/posters subsamples and conducting tests of moderation to determine whether the presentative path coefficients differed. Following Algesheimer, Dholakia, and Herrmann (2005), the process used was as follows for each test: Two multiple-sample models were created. In the first model called 'baseline' model in table 6, all paths were unconstrained between the two groups. In the second model (called 'equal paths' model in table 6), the

relevant path was constrained (e.g. self-categorization to community-based self-esteem for H3a) to be equal for both subsamples. The difference in chi-square values between the two models delivers a test of the equality of the path for the two groups. Table 6 summarizes these analyses and their results.

For lurkers versus posters, the results indicate that members' participation type moderates community-based self-esteem's effect on community affective commitment (this path is stronger for lurkers). The relationship between community affective commitment and 
affective brand commitment is slightly stronger for lurkers compared to posters. Moreover, the path from affective brand commitment to resistance to negative information is stronger for posters than for lurkers (supporting H8a). Figure 2 illustrates these results.

[Insert Figure 2 about here]

[Insert Table 6 about here]

\section{DISCUSSION AND CONCLUSIONS}

This study investigates the psychological effects of social identity in online brand communities and reveals the intermediate mechanisms mediating and moderating members' social identity effects on their commitment to the brand. This commitment to the brand is important for the downstream psychological effects tested, positive WOM and resistance to negative information. The results of this study strongly suggest that when examining social identity in OBCs, distinguishing between self-categorization, community affective commitment, and community-based self-esteem, as related but separate components of community members' social identity is possible and important. This allows organizations to formulate a successful branding strategy. Companies need a deeper understanding of how members’ social identity leads to their positive behavioral consequences in OBCs.

This study contributes to the literature on the role of the components of social identity and flow of influence in OBCs in four aspects. First, brand prestige and brand distinctiveness translate into and affect individuals' sense of identifying themselves as members of the 
community (self-categorization). Second, self-categorization and community-based selfesteem provide a basis for members' commitment towards the brand but community affective commitment is the direct determinant of their brand commitment. This means that without cultivating members' affective commitment to the community, members in an OBC may not necessarily become committed to the brand associated with the community. This reinforces the critical role of feelings of connection and belongingness towards the community in building members' brand commitment and positive behavioral consequences. Third, the findings of this research indicate that an important psychological effect of being part of an OBC is to cultivate customers brand commitment which leads to their greater positive WOM and higher resistance to negative information they may hear about the brand. Fourth, the results throw light on the relationship between cognitive, affective and evaluative components of social identity in OBCs for both posters and lurkers and also that these stimulate brand commitment, positive word-of-mouth and resistance to negative information for both groups.

The results in table 6 show that all the relationships in the model are significant for both posters and lurkers. However, the results for differences in relationships within the model by participation type are counter-intuitive. Rather than the relationships being stronger for posters than lurkers, for the majority of the hypotheses concerning participation type (HЗaH8a see table 6) this is not the case, in fact, only for H8a, affective brand commitment to resistance to negative information, is the path stronger for posters than lurkers. For all other relationships, apart from $\mathrm{H} 5 \mathrm{a}$ and $\mathrm{H6a}$, there are no significant differences in the path strength; for H5a and H6a, the relationship is reversed, the paths are stronger for lurkers than for posters. Taken together, these results suggest that although lurkers do not visibly participate in the community, they are as likely as posters to feel the sense of belonging to the 
community. They do see themselves as members, and so identify with the brand community and experience a social identity.

Theoretically, the significant and equal path coefficients suggest that the deductive route to social identity for lurkers holds not only for self-categorization as suggested by Cheng and Guo (2015) but also for community affective commitment, and community-based self-esteem. Social Cognitive Theory supports such a premise through the role of vicarious learning, perhaps assisted by which the information rich context of OBCs (Breitsohl, Kunz, \& Dowell, 2015). The feeling of self-esteem based on being important members of the community increased lurkers' commitment to the community and therefore to the brand itself. These relationships were significantly stronger than those of posters. This demonstrates an interesting finding as it might have been expected that these relationships should have been stronger for posters as they are the more active members. SCT and previous work on motivations for not posting can also help provide an explanation for these findings. First, in addition to this reversal in path coefficient strength to that expected, there is a significant difference between posters and lurkers in length of membership of the communities (chisquare $=24.84, d f=7, p<.01)$, that indicates lurkers are more likely to have shorter membership. Such a result is in line with previous research, such as Preece, Nonnecke, and Andrews (2004) and SCT predictions that newer or less experienced members will use vicarious learning to understand the community and the social norms around posting before participation. SCT predicts that an outcome of observation is establishment of self-efficacy, that is, confidence in performing a particular behavior (Bandura, 1971), in this case, posting information or questions. Previous research also finds that lurkers may not post because they believe they have nothing to add, or because of worries about others evaluations of their posts (Nonnecke, Preece, \& Andrews, 2004; Preece, Nonnecke, \& Andrews, 2004). Thus, lurkers may have lower self-efficacy regarding participation in OBCs. Gangadharbatla (2008) 
demonstrates a link between self-efficacy and collective self-esteem regarding use of social network services. Further, Lee, and Peccei, (2007) posit that fulfilling individuals' needs for esteem and approval leads to the development of a strong affective commitment to an organization. The lower self-efficacy likely felt by lurkers may mean that they are more likely to find greater psychological reward from perceived self-enhancement from their community membership and so a stronger path to community affective commitment.

The results also support our initial premise, not only are lurkers valid participants; they are also valuable community members. The results suggest that their vicarious experience in the OBC can, perhaps through observing the implicit social 'rules' expected in the community (Mottet \& Richmond, 1998; Argyle, 1992) or observing the sharing of positive social interactions, can result in strong, positive and significant path coefficients leading to positive WOM. They may not post information within the brand community, for several reasons (Nonnecke, Preece, \& Andrews, 2004; Preece, Nonnecke, \& Andrews, 2004), but seem to intend to be less restrained within their own networks. Silence within the OBC does not mean silence outside. The information rich context should provide lurkers with much positive WOM material.

Further, their vicarious experience is capable of strengthening attitudes and commitment to the brand by the affective and cognitive effects on how negative information is managed, as they also show significant path coefficients for resistance to negative information. This may be either through the effect of strong affective bonds on forgiveness (Eisingerich et al., 2011; Finkel et al., 2002) or rejection of negative information that might threaten a valued social identity. The resistance to negative information relationship may be stronger for posters, but stronger bonds are related to stronger social identity, which posters may acquire in some circumstances. Jans, Postmes, and Van der Zee (2012) find that in heterogeneous groups, inductive social identity formation can result in higher identification 
than deductive social identity formation. Where negative information is concerned, groups may be perceived as more heterogeneous, so in that circumstance, posters may have additional social identity resources that strengthen the relationship. Nevertheless, the significant paths show that the brand also benefits from rejection of negative information through social identity formation in lurkers.

\section{Recommendation of a Strategic Approach}

In conclusion, this study's results suggest that the affective component of social identity in an OBC is an important driver of members' commitment to the brand itself that increases their intention to talk positively about the brand and makes them more defensive of it. The brand's online community is not just a platform for the brand or an addition to the brand's communications mix but should be seen as absolutely central to develop their customer-brand relationships. Brands can do this by cultivating their customers' commitment to their online communities. A brand can use customers themselves to build long-term relationships in OBCs. When customers' self-concepts are linked to the community, then the company behind that brand may be able to gain an enduring competitive advantage since this type of connection is difficult for competitors to imitate (Escalas \& Bettman, 2003). Therefore, organizations should treat OBCs as strategic opportunities. Reciprocity between partners in an exchange relationship builds commitment. Companies should therefore, provide evidence of activity in the community, encouraging members to interact, listening to customers, providing them with high quality up-to-date information, and delivering rewards for members' contribution. The evidence from this study is that these features are equally important for lurkers and posters

Brand managers should consider both posters and lurkers and understand what both groups' feel they achieve and gain from visiting the OBC. They should make sure that 
members can interact freely with each other in a friendly online community, so that marketers can pursue customers' perceptions about and feelings toward the brand in real time (McWilliam, 2000). Brand managers can do this by increasing the access points to the online community (e.g., creating access to the community through mobile devices), and making it easy for members to express their feelings about and experiences with the brand. For instance, Mini Max USA, a manufacturer of wood working tools, allows its forum members to use a rich text editor, they can then change font size and color and use emotions (smiley conversational icons) and add web links (Adjei, Noble, \& Noble, 2012). Brand managers should make some informal and anonymous form of participation easy, e.g., pop-up polls on issues in addition to promoting posts. This should enable those who feel restrained or worried about their contribution to start to participate and gain positive psychological rewards. OBCs can be used as platforms for problem solving and sources of innovation (Füller, Jawecki, \& Mühlbacher, 2007; Füller, Matzler \& Hoppe, 2008). Brand managers could use crowdsourcing models (Brabham, 2008) that encourage simple participation that lurkers will be more willing to participate with, e.g., just a button press rather than leaving comments, lurkers may not post, but they might click.

Brand managers should do their best to implement a two-tier recognition system that rewards both posters' and lurkers' contribution and enable visits and reading of other posts to be rewarded in some way. They should try to track members' movements on their online communities and reward them appropriately. For example, the length of time spent on the community website, number of pages visited, items downloaded, referral, forwarding or resending the information to another party, in addition to the posting contribution. The results of this study suggest that referral, forwarding and re-sending are likely to be positively influenced by social identity formation for all brand community members, as they constitute a type of WOM behavior. Brands can reward both posters and lurkers by sending emails with 
discounts, invitations to special online events, or receive special offers to try new products or services. The provision of rich information will also provide material for more general WOM.

Moreover, managers should encourage all visitors to the OBC to get in touch directly with any issues they have, and make this easy with dedicated staff, for example using chat sessions, providing lists of frequently asked questions or company posts that show the brand listens to customers. All these activities will help members, both posters and lurkers, to feel that they are part of the community, increase their self-esteem, and so feel committed to the community and the brand itself.

Finally, the limitations of the present study suggest implications for future research. The sample members of this study are residents in the United States. Testing for crossnational and cross-cultural effects enhances the external validity of research results. The possible impact of other factors such as the size of the community, the level of member involvement, and the length of membership on self-categorization remain open for exploration. Although research into brand communities is well established, the same cannot be said about the research into the members' participation types, specifically the importance of lurkers. There is a need for further research into lurkers. Why do lurkers feel that they are important members of the community when they do not actively participate, and how can brands increase the feeling of social identity amongst lurkers in their online communities? Whilst there is a relationship between participation and length of OBC membership, there is still much unexplained about length of membership and its impact. Future research should investigate this relationship in more detail. Further, Breitsohl, Kunz and Dowell (2015) distinguish between firm hosted and customer led brand communities, this research focused on firm hosted OBCs, future research might investigate the model presented in this paper in other types of OBC. 


\section{REFERENCES}

Aaker, J. (1999). The malleable self: The tole of self-expression in persuasion. Journal of Marketing Research, 36(1), 45-57.

Aaker, J., Fournier, S., \& Brasel, S. A. (2004). When good brands do bad. Journal of Consumer Research, 31(1), 1-16.

Adjei, M. T., Noble, C. H., \& Noble, S. M. (2012). Enhancing relationships with customers through online brand communities. MIT Sloan Management Review, 53(4), 22-24.

Adjei, M. T., Noble, S. M., \& Noble, C. H. (2010). The influence of C2C communications in online brand communities on customer purchase behavior. Journal of the Academy of Marketing Science, 38(5), 634-653.

Ahearne, M., Bhattacharya, C. B., \& Gruen, T. (2005). Antecedents and consequences of customer-company identification: expanding the role of relationship marketing. Journal of Applied Psychology, 90(3), 574-585.

Ahluwalia, R., Burnkrant, R. E., \& Unnava, H. R. (2000). Consumer response to negative publicity: The moderating role of commitment. Journal of Marketing Research, 37(2), 203-214.

Algesheimer, R., Dholakia, U. M., \& Herrmann, A. (2005). The social influence of brand community: Evidence from European car clubs. Journal of Marketing, 69(3), 19-34.

Alicke, M. D., \& Sedikides, C. (Eds.). (2011). Handbook of self-enhancement and selfprotection. New York, NY: Guilford Press.

Anderson, J. C., \& Gerbing, D. W. (1988). Structural equation modeling in practice: A review and recommended two-step approach. Psychological Bulletin, 103(3), 411-423.

Andersson, L. M., \& Bateman, T. S. (1997). Cynicism in the workplace: Some causes and effects. Journal of Organizational Behavior, 18(5), 449-469.

Ashforth, B. E., \& Mael, F. (1989). Social identity theory and the organization. Academy of Management Review, 14(1), 20-39.

Ashforth, B. E., Harrison, S. H., \& Corley, K. G. (2008). Identification in organizations: An examination of four fundamental questions. Journal of Management, 34(3), 325-374.

Ashley, C., \& Tuten, T. (2015). Creative strategies in social media marketing: An exploratory study of branded social content and consumer engagement. Psychology \& Marketing, 32(1), 15-27.

Argyle, M. (1992). The social psychology of everyday life. London: Routledge. 
Baek, T. H., Kim, J., \& Yu, J. H. (2010). The differential roles of brand credibility and brand prestige in consumer brand choice. Psychology \& Marketing, 27(7), 662-678.

Bagozzi, R. P. (1995). Reflections on relationship marketing in consumer markets. Journal of the Academy of Marketing Science, 23(4), 272-277.

Bagozzi, R. P., \& Dholakia, U. M. (2002). Intentional social action in virtual communities. Journal of Interactive Marketing, 16(2), 2-21.

Bagozzi, R. P., \& Dholakia, U. M. (2006). Antecedents and purchase consequences of customer participation in small group brand communities. International Journal of Research in Marketing, 23(1), 45-61.

Bagozzi, R. P., \& Yi, Y. (1988). On the evaluation of structural equation models. Journal of the Academy of Marketing Science, 16(1), 74-94.

Bandura, A. (1971). Vicarious- and self-reinforcement processes. In R. Glaser (Ed.), The nature of reinforcement (pp. 228 -278). New York, NY: Academic Press.

Bandura, A. (1986). Social foundations of thought and action: A social cognitive theory. Englewood Cliffs, NJ: Prentice Hall, Inc.

Bansal, H. S., Irving, P. G., \& Taylor, S. F. (2004). A three-component model of customer commitment to service providers. Journal of the Academy of Marketing Science, 32(3), 234-250.

Bateman, P. J., Gray, P. H., \& Butler, B. S. (2011). Research note-the impact of community commitment on participation in online communities. Information Systems Research, 22(4), 841-854.

Bergami, M., \& Bagozzi, R. P. (2000). Self-categorization, affective commitment and group self-esteem as distinct aspects of social identity in the organization. British Journal of Social Psychology, 39(4), 555-577.

Bhattacharya, C. B., \& Sen, S. (2003). Consumer-company identification: A framework for understanding consumers’ relationships with companies. Journal of Marketing, 67(2), 76-88.

Bhattacharya, C. B., Rao, H., \& Glynn, M. A. (1995). Understanding the bond of identification: An investigation of its correlates among art museum members. Journal of Marketing, 59(4), 46-57.

Blanton, H., \& Christie, C. (2003). Deviance regulation: A theory of action and identity. Review of General Psychology, 7(2), 115-149. 
Boomsma, A., \& Hoogland, J. J. (2001). The robustness of LISREL modeling revisited. In R. Cudeck, S. du Toit, \& D. Sorbom (Eds.), Structural equation modeling: Present and * future (pp. 1-25). Chicago, IL: Scientific Software International Inc.

Brabham, D. C. (2008). Crowdsourcing as a model for problem solving an introduction and cases. Convergence: The International Journal of Research into New Media Technologies, 14(1), 75-90.

Breitsohl, J., Kunz, W. H., \& Dowell, D. (2015). Does the host match the content? A taxonomical update on online consumption communities. Journal of Marketing Management, 31(9-10), 1040-1064.

Brodie, R. J., Ilic, A., Juric, B., \& Hollebeek, L. (2013). Consumer engagement in a virtual brand community: An exploratory analysis. Journal of Business Research, 66(1), 105114.

Brown, S. G. (1969). Laws of form. London: Allen and Unwin.

Brown, T. J., Barry, T. E., Dacin, P. A., \& Gunst, R. F. (2005). Spreading the word: Investigating antecedents of consumers' positive word-of-mouth intentions and behaviors in a retailing context. Journal of the Academy of Marketing Science, 33(2), 123-138.

Brown, R., Condor, S., Mathews, A., Wade, G., \& Williams, J. (1986). Explaining intergroup differentiation in an industrial organization. Journal of Occupational Psychology, 59(4), 273-286.

Burmann, C., \& Zeplin, S. (2005). Building brand commitment: A behavioral approach to internal brand management. The Journal of Brand Management, 12(4), 279-300.

Byrne, B. M. (2013). Structural equation modeling with AMOS: Basic concepts, applications, and programming. New York, NY: Routledge.

Byrne, B. M., \& Watkins, D. (2003). The issue of measurement invariance revisited. Journal of Cross-Cultural Psychology, 34(2), 155-175.

Carlson, B. D., Suter, T. A., \& Brown, T. J. (2008). Social versus psychological brand community: The role of psychological sense of brand community. Journal of Business Research, 61(4), 284-291.

Cater, B., \& Zabkar, V. (2009). Antecedents and consequences of commitment in marketing research services: The client's perspective. Industrial Marketing Management, 38(7), 785-797.

Chan, K. W., \& Li, S. Y. (2010). Understanding consumer-to-consumer interactions in virtual communities: The salience of reciprocity. Journal of Business Research, 63(9), 10331040. 
Cheney, G. C. (1983). On the various and changing meanings of organizational membership: A field study of organizational identification. Communication Monographs, 50(4), 342-362.

Cheng, Z. C., \& Guo, T. C. (2015). The formation of social identity and self-identity based on knowledge contribution in virtual communities: An inductive route model. Computers in Human Behavior, 43, 229-241.

Cheung, G. W. (2008). Testing equivalence in the structure, means, and variances of higherorder constructs with structural equation modeling. Organizational Research Methods, 11(3), 593-613.

Currás-Pérez, R. C. (2009). Effects of perceived identity based on corporate social responsibility: the role of consumer identification with the company. Corporate Reputation Review, 12(2), 177-191.

Currás-Pérez, R., Bigné-Alcañiz, E., \& Alvarado-Herrera, A. (2009). The role of selfdefinitional principles in consumer identification with a socially responsible company. Journal of Business Ethics, 89(4), 547-564.

Dholakia, U. M., Blazevic, V., Wiertz, C., \& Algesheimer, R. (2009). Communal service delivery how customers benefit from participation in firm-hosted virtual P3 communities. Journal of Service Research, 12(2), 208-226.

Dimitriadis, S., \& Papista, E. (2010). Integrating relationship quality and consumer-brand identification in building brand relationships: proposition of a conceptual model. The Marketing Review, 10(4), 385-401.

Dutton, J. E., \& Dukerich, J. M. (1991). Keeping an eye on the mirror: Image and identity in organizational adaptation. Academy of Management Journal, 34(3), 517-554.

Einwiller, S. A., Fedorikhin, A., Johnson, A. R., \& Kamins, M. A. (2006). Enough is enough! When identification no longer prevents negative corporate associations. Journal of the Academy of Marketing Science, 34(2), 185-194.

Eisenbeiss, M., Blechschmidt, B., Backhaus, K., \& Freund, P. A. (2012). “The (real) world is not enough:" motivational drivers and user behavior in virtual worlds. Journal of Interactive Marketing, 26(1), 4-20.

Eisenberg, N., \& Miller, P. A. (1987). The relation of empathy to prosocial and related behaviors. Psychological Bulletin, 101(1), 91-119.

Eisingerich, A. B., Rubera, G., Seifert, M., \& Bhardwaj, G. (2011). Doing good and doing better despite negative information? The role of corporate social responsibility in consumer resistance to negative information. Journal of Service Research, 14(1), 6075. 
Elbedweihy, A. M., Jayawardhena, C., Elsharnouby, M. H., \& Elsharnouby, T. H. (2016). Customer relationship building: The role of brand attractiveness and consumer-brand identification. Journal of Business Research, 69(8), 2901-2910.

Ellemers, N., Kortekaas, P., \& Ouwerkerk, J. W. (1999). Self-categorisation, commitment to the group and group self-esteem as related but distinct aspects of social identity. European Journal of Social Psychology, 29(23), 371-389.

Escalas, J. E., \& Bettman, J. R. (2003) You are what they eat: The influence of reference groups on consumers' connections to brands. Journal of Consumer Psychology, 13(3), 339-348.

Finkel, E. J., Rusbult, C. E., Kumashiro, M., \& Hannon, P. A. (2002). Dealing with betrayal in close relationships: does commitment promote forgiveness?. Journal of Personality and Social Psychology, 82(6), 956.

Fornell, C., \& Larcker, D. F. (1981). Evaluating structural equation models with unobservable variables and measurement error. Journal of Marketing Research, 18(1), 39-50.

Füller, J., Jawecki, G., \& Mühlbacher, H. (2007). Innovation creation by online basketball communities. Journal of Business Research, 60(1), 60-71.

Füller, J., Matzler, K., \& Hoppe, M. (2008). Brand community members as a source of innovation. Journal of Product Innovation Management, 25(6), 608-619.

Fullerton, G. (2005). The impact of brand commitment on loyalty to retail service brands. Canadian Journal of Administrative Sciences/Revue Canadienne des Sciences de l'Administration, 22(2), 97-110.

Gangadharbatla, H. (2008). Facebook me: Collective self-esteem, need to belong, and internet self-efficacy as predictors of the iGeneration's attitudes toward social networking sites. Journal of Interactive Advertising, 8(2), 5-15.

Gruen, T. W., Summers, J. O., \& Acito, F. (2000). Relationship marketing activities, commitment, and membership behaviors in professional associations. Journal of Marketing, 64(3), 34-49.

Gustafsson, A., Johnson, M. D., \& Roos, I. (2005). The effects of customer satisfaction, relationship commitment dimensions, and triggers on customer retention. Journal of Marketing, 69(4), 210-218.

Hagel, J., \& Armstrong, A. G. (1997). Net gain: Expanding markets through virtual communities. Boston, MA Harvard Business School Press.

Hair, J. F., William B., Barry J. B., \& Rolph E. A. (2010). Multivariate data analysis: A global perspective (7th ed.). New Jersey: Pearson Education, Inc. 
Hair, J. F., William B., Barry J. B., \& Rolph E. A. (2014). Multivariate data analysis: Pearson new international edition. Essex: Pearson Education Limited.

Hartmann, B. J., Wiertz, C., \& Arnould, E. J. (2015). Exploring consumptive moments of value-creating practice in online community. Psychology \& Marketing, 32(3), 319340.

Hollebeek, L. D., Glynn, M. S., \& Brodie, R. J. (2014). Consumer brand engagement in social media: Conceptualization, scale development and validation. Journal of Interactive Marketing, 28(2), 149-165.

Hornsey, M. J. (2008). Social identity theory and self-categorization theory: A historical review. Social and Personality Psychology Compass, 2(1), 204-222.

Jackson, J. W., \& Smith, E. R. (1999). Conceptualizing social identity: A new framework and evidence for the impact of different dimensions. Personality and Social Psychology Bulletin, 25(1), 120-135.

Jans, L., Postmes, T., \& Van der Zee, K. I. (2012). Sharing differences: The inductive route to social identity formation. Journal of Experimental Social Psychology, 48(5), 11451149.

Jiménez, F. R., \& Mendoza, N. A. (2013). Too popular to ignore: The influence of online reviews on purchase intentions of search and experience products. Journal of Interactive Marketing, 27(3), 226-235.

Johnson, D. S., \& Lowe, B. (2015). Emotional support, perceived corporate ownership and skepticism toward out-groups in virtual communities. Journal of Interactive Marketing, 29, 1-10.

Jöreskog, K. G., \& Sörbom, D. (1996). LISREL 8: User's reference guide. Chicago, IL: Scientific Software International.

Kim, J. W., Choi, J., Qualls, W., \& Han, K. (2008). It takes a marketplace community to raise brand commitment: the role of online communities. Journal of Marketing Management, 24(3-4), 409-431.

Koll, O., von Wallpach, S., \& Kreuzer, M. (2010). Multi-method research on consumerbrand associations: Comparing free associations, storytelling, and collages. Psychology \& Marketing, 27(6), 584-602.

Kuenzel, S., \& Vaux Halliday, S. (2008). Investigating antecedents and consequences of brand identification. Journal of Product \& Brand Management, 17(5), 293-304.

Lai, H. M., \& Chen, T. T. (2014). Knowledge sharing in interest online communities: A comparison of posters and lurkers. Computers in Human Behavior, 35, 295-306. 
Lee, J., \& Peccei, R. (2007). Perceived organizational support and affective commitment: the mediating role of organization-based self-esteem in the context of job insecurity. Journal of Organizational Behavior, 28(6), 661-685.

Lam, S. K. (2012). Identity-motivated marketing relationships: research synthesis, controversies, and research agenda. AMS review, 2(2-4), 72-87.

Lariviere, B., Keiningham, T. L., Cooil, B., Aksoy, L., \& Malthouse, E. C. (2014). A longitudinal examination of customer commitment and loyalty. Journal of Service Management, 25(1), 75-100.

Li, Z. G., \& Dant, R. P. (1997). An exploratory study of exclusive dealing in channel relationships. Journal of the Academy of Marketing Science, 25(3), 201-213.

Luhtanen, R., \& Crocker, J. (1992). A collective self-esteem scale: Self-evaluation of one's social identity. Personality and Social Psychology Bulletin, 18(3), 302-318.

Mael, F., \& Ashforth, B. E. (1992). Alumni and their alma mater: A partial test of the reformulated model of organizational identification. Journal of Organizational Behavior, 13(2), 103-123.

Marin, L., \& Ruiz, S. (2007). “I need you too!” Corporate identity attractiveness for consumers and the role of social responsibility. Journal of Business Ethics, 71(3), 245-260.

McWilliam, G. (2000). Building stronger brands through online communities. Sloan Management Review, 41(3), 43-54.

Meyer, J. P., \& Allen, N. J. (1991). A three-component conceptualization of organizational commitment. Human Resource Management Review, 1(1), 61-89.

Meyer, J. P., \& Allen, N. J. (1997). Commitment in the workplace:Theory, research and application, Thousand Oaks, CA: Sage Publications.

Mottet, T. P., \& Richmond, V. P. (1998). An inductive analysis of verbal immediacy: Alternative conceptualization of relational verbal approach/avoidance strategies. Communication Quarterly, 46(1), 25-40.

Muniz Jr, A. M., \& O’Guinn, T. C. (2001). Brand community. Journal of Consumer Research, 27(4), 412-432.

Nielsen, J. (2006). The 90-9-1 rule for participation inequality in social media and online communities. Retrieved from http://www.nngroup.com/articles/participationinequality/ (Accessed 9 November 2015) 
Nonnecke, B., \& Preece, J. (2000, April). Lurker demographics: Counting the silent. In Proceedings of the SIGCHI conference on Human Factors in Computing Systems (pp. 73-80). ACM.

Nonnecke, B., Preece, J., \& Andrews, D. (2004). What lurkers and posters think of each other. In Proceedings of the 37th Annual Hawaii International Conference on System Sciences (pp. 195-203). IEEE Computer Society.

Nunnally, J. C. (1978). Psychometric theory, New York, NY: McGraw-Hill.

Pagiaslis, A., \& Krontalis, A. K. (2014). Green consumption behavior antecedents: Environmental concern, knowledge, and beliefs. Psychology \& Marketing, 31(5), 335-348.

Pagani, M., Hofacker, C. F., \& Goldsmith, R. E. (2011). The influence of personality on active and passive use of social networking sites. Psychology \& Marketing, 28(5), 441-456.

Peltier, J. W., Zahay, D., \& Lehmann, D. R. (2013). Organizational learning and CRM success: a model for linking organizational practices, customer data quality, and performance. Journal of Interactive Marketing, 27(1), 1-13.

Podsakoff, P. M., MacKenzie, S. B., \& Podsakoff, N. P. (2012). Sources of method bias in social science research and recommendations on how to control it. Annual Review of Psychology, 63(1), 539-569.

Podsakoff, P. M., MacKenzie, S. B., Lee, J. Y., \& Podsakoff, N. P. (2003). Common method biases in behavioral research: a critical review of the literature and recommended remedies. Journal of Applied Psychology, 88(5), 879.

Porter, C. E., \& Donthu, N. (2008). Cultivating trust and harvesting value in virtual communities. Management Science, 54(1), 113-128.

Postmes, T., Haslam, S. A., \& Swaab, R. I. (2005). Social influence in small groups: An interactive model of social identity formation. European Review of Social Psychology, 16(1), 1-42.

Postmes, T., Spears, R., Lee, A. T., \& Novak, R. J. (2005). Individuality and social influence in groups: inductive and deductive routes to group identity. Journal of Personality and Social Psychology, 89(5), 747.

Preece, J., Nonnecke, B., \& Andrews, D. (2004). The top five reasons for lurking: improving community experiences for everyone. Computers in Human Behavior, 20(2), 201-223.

Ratchford, B. T. (2015). Some directions for research in interactive marketing. Journal of Interactive Marketing, 29, v-vii. 
Ridings, C., Gefen, D., \& Arinze, B. (2006). Psychological barriers: Lurker and poster motivation and behavior in online communities. Communications of the Association for Information Systems, 18(1), 16.

Schlosser, A. E. (2005). Posting versus lurking: Communicating in a multiple audience context. Journal of Consumer Research, 32(2), 260-265.

Schneider, A., Von Krogh, G., \& JäGer, P. (2013). “What’s coming next?” Epistemic curiosity and lurking behavior in online communities. Computers in Human Behavior, 29(1), 293-303.

Schumacker, R. E., \& Lomax, R. G. (2004). A beginner's guide to structural equation modeling, Second edition. Mahwah, NJ: Lawrence Erlbaum Associates.

Shankar, V., \& Batra, R. (2009). The growing influence of online marketing communications. Journal of Interactive Marketing, 23(4), 285-287.

Sirgy, M. J. (1982). Self-concept in consumer behavior: A critical review. Journal of Consumer Research, 9(3), 287-300.

Slade, E. L., Dwivedi, Y. K., Piercy, N. C., \& Williams, M. D. (2015). Modeling consumers’ adoption intentions of remote mobile payments in the United Kingdom: Extending UTAUT with innovativeness, risk, and trust. Psychology \& Marketing, 32(8), 860873.

Smidts, A., Pruyn, A. T. H., \& Van Riel, C. B. (2001). The impact of employee communication and perceived external prestige on organizational identification. Academy of Management Journal, 44(5), 1051-1062.

Steinmann, S., Mau, G., \& Schramm-Klein, H. (2015). Brand communication success in online consumption communities: An experimental analysis of the effects of communication style and brand pictorial representation. Psychology \& Marketing, 32(3), 356-371.

Stokburger-Sauer, N. (2010). Brand community: drivers and outcomes. Psychology \& Marketing, 27(4), 347-368.

Stokburger-Sauer, N. E., \& Wiertz, C. (2015). Online consumption communities: An introduction. Psychology \& Marketing, 32(3), 235-239

Stokburger-Sauer, N., Ratneshwar, S., \& Sen, S. (2012). Drivers of consumer-brand identification. International Journal of Research in Marketing, 29(4), 406-418.

Suh, A. (2013). The influence of self-discrepancy between the virtual and real selves in virtual communities. Computers in Human Behavior, 29(1), 246-256. 
Tajfel, H. (1978). Differentiation between social groups: Studies in the social psychology of intergroup relations. London: Academic Press.

Tajfel, H. (1981). Human groups and social categories. Cambridge, UK: Cambridge University Press.

Tajfel, H., \& Turner, J. C. (1979). Social psychology of intergroup relations, Monterey, CA: Brooks/Cole CA.

Tajfel, H., \& Turner, J. C. (2004). The social identity theory of intergroup behavior. In J. T. Jost, \& J. SidaniusJos, (Eds.), Political psychology: Key readings, New York, NY: Psychology Press.

Tsai, H. T., \& Bagozzi, R. P. (2014). Contribution behavior in virtual communities: Cognitive, emotional, and social influences. MIS Quarterly, 38(1), 143-163.

Turner, J. C. (1982) Toward a cognitive redefinition of the social group. In: Tajfel, H. (ed.) Social identity and intergroup behavior. Cambridge, England: Cambridge University Press.

Van Dick, R. (2001). Identification in organizational contexts: Linking theory and research from social and organizational psychology. International Journal of Management Reviews, 3(4), 265-283.

Van Dick, R., Wagner, U., Stellmacher, J., \& Christ, O. (2004). The utility of a broader conceptualization of organizational identification: Which aspects really matter? Journal of Occupational and Organizational Psychology, 77(2), 171-191.

Walker, B., Redmond, J., \& Lengyel, A. (2013). Are They All The Same? Lurkers and Posters on The Net. eCULTURE, 3(1), 16.

Wirtz, J., den Ambtman, A., Bloemer, J., Horváth, C., Ramaseshan, B., van de Klundert, J., Gurhan Canli, Z., \& Kandampully, J. (2013). Managing brands and customer engagement in online brand communities. Journal of Service Management, 24(3), 223-244.

Wolter, J. S., \& Cronin Jr, J. J. (2015). Re-conceptualizing cognitive and affective customercompany identification: The role of self-motives and different customer-based outcomes. Journal of the Academy of Marketing Science, 44(3), 397-413.

Wulf, K. D., Odekerken-Schröder, G., \& Iacobucci, D. (2001). Investments in consumer relationships: a cross-country and cross-industry exploration. Journal of Marketing, 65(4), 33-50.

Zaglia, M. E. (2013). Brand communities embedded in social networks. Journal of Business Research, 66(2), 216-223. 
Zeithaml, V. A., Berry, L. L., \& Parasuraman, A. (1996). The behavioral consequences of service quality. Journal of Marketing, 60(2), 31-46.

Zhao, X., Lynch, J. G., \& Chen, Q. (2010). Reconsidering baron and kenny: Myths and truths about mediation analysis. Journal of Consumer Research, 37(2), 197-206.

Zhou, Z., Wu, J. P., Zhang, Q., \& Xu, S. (2013). Transforming visitors into members in online brand communities: Evidence from China. Journal of Business Research, 66(12), 2438-2443.

Zhou, Z., Zhang, Q., Su, C., \& Zhou, N. (2012). How do brand communities generate brand relationships? Intermediate mechanisms. Journal of Business Research, 65(7), 890895. 
Table 1: Posters and lurkers profile

\begin{tabular}{l|c|c}
\hline Profile & $\begin{array}{c}\text { Posters (N=337) } \\
\text { Frequency (percent) }\end{array}$ & $\begin{array}{c}\text { Lurkers (N=415) } \\
\text { Frequency (percent) }\end{array}$ \\
\hline Gender & $183(54 \%)$ & $177(43 \%)$ \\
Male & $154(46 \%)$ & $238(57 \%)$ \\
Female & & \\
\hline Age & $2(.5 \%)$ & $3(.7 \%)$ \\
$18 \_20$ & $75(22 \%)$ & $65(16 \%)$ \\
$21 \_30$ & $100(30 \%)$ & $98(24 \%)$ \\
$31 \_40$ & $68(20 \%)$ & $83(20 \%)$ \\
$41 \_50$ & $76(22.5 \%)$ & $125(30 \%)$ \\
$51 \_65$ & $16(5 \%)$ & $41(9.3 \%)$ \\
Over65 & & \\
\hline Tenure & $7(2 \%)$ & $32(8 \%)$ \\
Less than 3 months & $20(6 \%)$ & $33(8 \%)$ \\
3 months $<6$ months & $39(12 \%)$ & $69(17 \%)$ \\
6 months $<1$ year & $78(23 \%)$ & $105(25 \%)$ \\
1 year $<2$ years & $85(25 \%)$ & $74(18 \%)$ \\
2 years $<3$ years & $46(14 \%)$ & $43(11 \%)$ \\
3 years $<4$ years & $18(5 \%)$ & $15(4 \%)$ \\
4 years $<5$ years & $44(13 \%)$ & $44(11 \%)$ \\
5 years and more & & \\
\hline
\end{tabular}


Table 2: Measurement Items and Validity Assessment

\section{Constructs and Indicators}

SFL

Brand Prestige (Cronbach's $\alpha=.90$ )

This brand is very prestigious

This brand has high status

This brand is very upscale

Brand distinctiveness (Cronbach's $\alpha=.84$ )

This brand has a distinctive identity

This brand is unique

This brand stands out from its competitors

Self-categorization (Cronbach's $\alpha=.92$ )

8-point visual and verbal presentation

Please indicate to what degree your self-image overlaps with the identity of this community as you perceive it

Community-based self-esteem (Cronbach's $\alpha=.94$ )

I am a valuable member of this community

I am an important member of this community

I feel I have much to offer to this community

I am a cooperative participant in this community

Community affective commitment (Cronbach's $\alpha=.96$ )

How attached are you to this community?

How strong would you say your feelings of belongingness are toward this community?

How strong a connection do you feel to this community?

To what extent does this community have a great deal of personal meaning for you?

Affective brand commitment (Cronbach's $\alpha=.96$ )

I feel like this brand is part of my family

I feel emotionally attached to this brand

This brand has a great deal of personal meaning for me

I feel a strong sense of belonging to this brand

Resistance to negative information (Cronbach's $\alpha=.90$ )

Negative information about this brand does not change my general view of the brand

I hardly change my view of this brand based on negative information about it

Negative information about this brand changes the way I think of the brand (R)

I say positive things about this brand to other people $\quad .91$

I recommend this brand to someone who seeks my advice 94

I encourage friends and relatives to do business with this brand $\quad .87$

Note: SFL = standardized factor loadings; (R) Reverse coded 
Table 3: Construct Measure Descriptive Statistics

\begin{tabular}{lcccccccc}
\hline Constructs & 1 & 2 & 3 & 4 & 5 & 6 & 7 & 8 \\
\hline 1. Brand prestige & $\mathbf{. 7 6}$ & & & & & & & \\
2. Brand distinctiveness & .48 & $\mathbf{. 6 5}$ & & & & & & \\
3. Self-categorization & .22 & .19 & $\mathbf{. 8 5}$ & & & & & \\
4. Community affective commitment & .21 & .23 & .55 & $\mathbf{. 8 7}$ & & & & \\
5. Community self-esteem & .17 & .16 & .42 & .66 & $\mathbf{. 8 0}$ & & & \\
6. Affective brand commitment & .24 & .30 & .43 & .42 & .59 & $\mathbf{. 8 6}$ & & \\
7. Resistance to negative information & .21 & .25 & .09 & .12 & .13 & .17 &. $\mathbf{7 0}$ & \\
8. Word of mouth & .35 & .50 & .22 & .21 & .28 & .33 & .31 & $\mathbf{. 8 3}$ \\
Composite Reliability & .91 & .85 & .92 & .96 & .94 & .96 & .90 & .94 \\
Mean & 6.8 & 7.5 & 5.2 & 6.0 & 6.0 & 5.9 & 6.7 & 7.6 \\
Standard Deviation & 1.6 & 1.2 & 1.8 & 1.9 & 1.9 & 2.2 & 1.7 & 1.4 \\
\hline
\end{tabular}

Notes: Bold figures on the diagonal are the AVE for the constructs. Lower diagonal represent squared correlations. All correlations are significant at $p<.001$ 
Table 4: Structural Model Results

\begin{tabular}{|c|c|c|c|c|}
\hline Hypotheses & Relationship & Std. $^{a}$ & $p$ & Findings \\
\hline H1 & Brand prestige $\rightarrow$ Self-categorization & .32 & $* * *$ & Supported \\
\hline $\mathrm{H} 2$ & Brand distinctiveness $\rightarrow$ Self-categorization & .24 & $* * *$ & Supported \\
\hline H3 & $\begin{array}{l}\text { Self-categorization } \rightarrow \text { Community-based } \\
\text { self-esteem }\end{array}$ & .65 & $* * *$ & Supported \\
\hline $\mathrm{H} 4$ & $\begin{array}{l}\text { Self-categorization } \rightarrow \text { Community affective } \\
\text { commitment }\end{array}$ & .39 & $* * *$ & Supported \\
\hline H5 & $\begin{array}{l}\text { Community-based self-esteem } \rightarrow \\
\text { Community affective commitment }\end{array}$ & .56 & $* * *$ & Supported \\
\hline H6 & $\begin{array}{l}\text { Community affective commitment } \rightarrow \\
\text { affective brand commitment }\end{array}$ & .78 & $* * *$ & Supported \\
\hline H7 & $\begin{array}{l}\text { Affective brand commitment } \rightarrow \text { Positive } \\
\text { WOM }\end{array}$ & .58 & $* * *$ & Supported \\
\hline H8 & $\begin{array}{l}\text { Affective brand commitment } \rightarrow \text { Resistance } \\
\text { to Negative Information }\end{array}$ & .43 & $* * *$ & Supported \\
\hline
\end{tabular}

Note: ${ }^{a}$ Standardized Regression Weights $* * * p<0.001$ 
Table 5: Mediation analysis

\begin{tabular}{cllccc}
\hline \multicolumn{1}{c}{$\begin{array}{c}\text { Independent } \\
\text { Variable }\end{array}$} & $\begin{array}{c}\text { Dependent } \\
\text { Variable }\end{array}$ & Mediator & $\begin{array}{c}\text { Indirect effect } \\
\text { Standardized } \\
\text { Coef }\end{array}$ & $\begin{array}{c}\text { Direct effect } \\
\text { Standardized } \\
\text { Coef }\end{array}$ & Result \\
\hline Self-categorization & $\begin{array}{l}\text { Affective } \\
\text { brand } \\
\text { commitment }\end{array}$ & $\begin{array}{l}\text { Community } \\
\text { affective } \\
\text { commitment }\end{array}$ & $.47^{* * *}$ & $.20^{* * *}$ & $\begin{array}{c}\text { Partial } \\
\text { Mediation }\end{array}$ \\
$\begin{array}{l}\text { Community-based } \\
\text { self-esteem }\end{array}$ & $\begin{array}{l}\text { Affective } \\
\text { brand } \\
\text { commitment }\end{array}$ & $\begin{array}{l}\text { Community } \\
\text { affective } \\
\text { commitment }\end{array}$ & $.34^{* * *}$ & $.03(\mathrm{~ns})$ & Mediation \\
\hline
\end{tabular}

**Sig. at $p<.001$. 
Table 6: Results of moderating effects of members' participation type

\begin{tabular}{|c|c|c|}
\hline Hypothesis & $\begin{array}{l}\text { Path Coefficients in } \\
\text { Unconstrained Model }\end{array}$ & $\chi^{2}$ Test Results \\
\hline Baseline Model & & $\begin{array}{c}\text { No constraints model: } \\
\chi^{2}(630)=1897.679\end{array}$ \\
\hline $\begin{array}{l}\text { H3a } \\
\text { Self-categorization } \rightarrow \\
\text { Community-based self- } \\
\text { esteem }\end{array}$ & $\begin{array}{c}\beta_{(\mathrm{L})}=.60^{* * *} \\
\beta_{(\mathrm{P})}=.57^{* * *} \\
\text { H3a: Rejected }\end{array}$ & $\begin{array}{l}\text { Equal path model: } \\
\begin{array}{c}\chi^{2}(631)=1897.686 \\
\chi_{\mathrm{d}}^{2}(1)=.007 \\
p>.90\end{array}\end{array}$ \\
\hline $\begin{array}{l}\text { H4a } \\
\text { Self-categorization } \rightarrow \\
\text { Community affective } \\
\text { commitment }\end{array}$ & $\begin{array}{c}\beta_{(\mathrm{L})}^{\mathrm{a}}=.36^{* * * \mathrm{~b}} \\
\beta_{(\mathrm{P})}=.47^{* * *} \\
\text { H4a: Rejected }\end{array}$ & $\begin{array}{l}\text { Equal path model: } \\
\begin{array}{c}\chi^{2}(631)=1898.691 \\
\chi_{d}^{2}(1)=1.012 \\
p>.30\end{array}\end{array}$ \\
\hline $\begin{array}{l}\text { H5a } \\
\text { Community-based self- } \\
\text { esteem } \rightarrow \text { Community } \\
\text { affective commitment }\end{array}$ & $\begin{array}{c}\beta_{(\mathrm{L})}=.58^{* * *} \\
\beta_{(\mathrm{P})}=.48^{* * *} \\
\text { H5a: Rejected } \\
\text { However the path is } \\
\text { stronger (at a significant } \\
\text { level) for lurkers than } \\
\text { posters }\end{array}$ & $\begin{array}{l}\text { Equal path model: } \\
\begin{array}{c}\chi^{2}(631)=1907.968 \\
\chi_{d}^{2}(1)=10.289 \\
p<.005\end{array}\end{array}$ \\
\hline $\begin{array}{l}\text { H6a } \\
\text { Community affective } \\
\text { commitment } \rightarrow \text { Affective } \\
\text { brand commitment }\end{array}$ & $\begin{array}{c}\beta_{(\mathrm{L})}=.75^{* * *} \\
\beta_{(\mathrm{P})}=.74^{* * *} \\
\text { H6a: Rejected } \\
\text { However the path is } \\
\text { stronger (at a significant } \\
\text { level) for lurkers than } \\
\text { posters }\end{array}$ & $\begin{array}{l}\text { Equal path model: } \\
\begin{array}{c}\chi^{2}(631)=1903.534 \\
\chi_{d}^{2}(1)=5.855 \\
p<.05\end{array}\end{array}$ \\
\hline $\begin{array}{l}\text { H7a } \\
\text { Affective brand commitment } \\
\rightarrow \text { Positive word of mouth }\end{array}$ & $\begin{array}{c}\beta_{(\mathrm{L})}=.53^{* * *} \\
\beta_{(\mathrm{P})}=.62^{* * *} \\
\text { H7a: Rejected }\end{array}$ & $\begin{array}{l}\text { Equal path model: } \\
\begin{array}{c}\chi^{2}(631)=1897.931 \\
\chi_{\mathrm{d}}^{2}(1)=.252 \\
p>.60\end{array}\end{array}$ \\
\hline
\end{tabular}




\begin{tabular}{|l|cc|}
\hline Hypothesis & $\begin{array}{c}\text { Path Coefficients in } \\
\text { Unconstrained Model }\end{array}$ & $\chi^{2}$ Test Results \\
\hline H8a & $\beta_{(\mathrm{L})}=.35^{* * *}$ & Equal path model: \\
Affective brand commitment & $\beta_{(\mathrm{P})}=.52^{* * *}$ & $\chi^{2}(631)=1906.726$ \\
$\rightarrow$ Resistance to negative & H8a Supported & $\chi_{\mathrm{d}}^{2}(1)=9.047$ \\
information & & $p<.005$ \\
\hline
\end{tabular}

aThe subscript " $L$ " refers to the lurkers subsample, and "P" refers to the posters subsample.

${ }^{\mathrm{b}}$ Standardized coefficient.

*** $p<.005$

${ }^{* *} p<.05$ 
Figure1: Conceptual Research Model

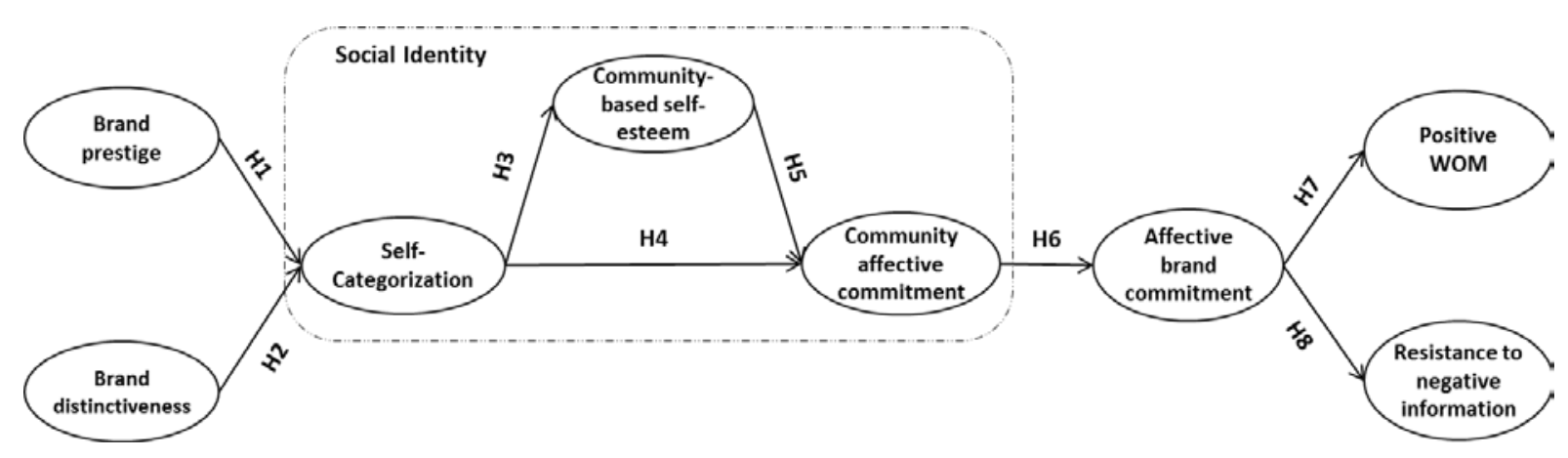


Figure 2: Comparison between Posters and Lurkers

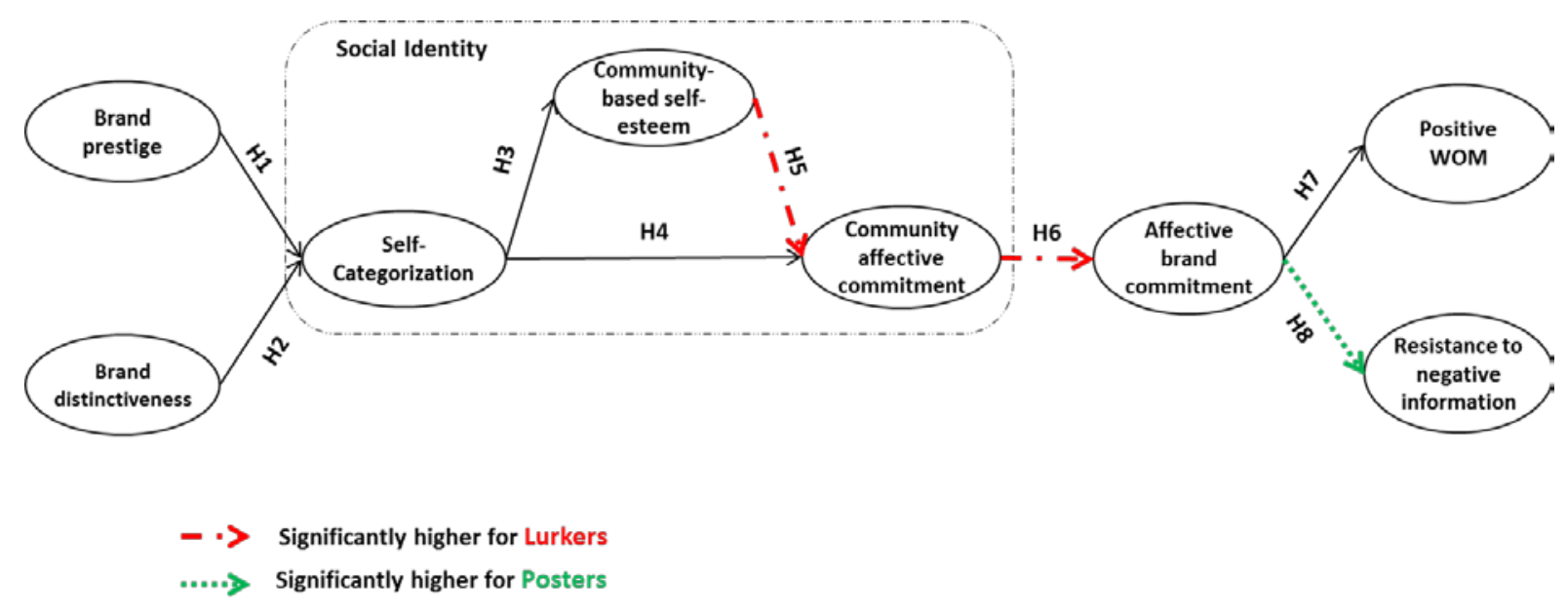




\section{Appendix A}

Summary of Fit Statistics for Testing Measurement Invariance of the Model for Posters / Lurkers Groups

\begin{tabular}{ccccccccc}
\hline Model & $\chi^{2}$ & df & RMSEA & CFI & $\begin{array}{c}\text { Model } \\
\text { Comparison }\end{array}$ & $\Delta \chi^{2}$ & $\Delta$ df & $P$ \\
\hline
\end{tabular}

Separate groups

\begin{tabular}{|c|c|}
\hline Lurkers & 636.490 \\
\hline Posters & 622.096 \\
\hline
\end{tabular}

Model 1

$\begin{array}{llll}1336.069 & 592 \quad .041 \quad .96\end{array}$

Configural Invariance

\section{Model 2}

All factor loadings

$1392.540 \quad 611$

.041

.96

2 vs. 1

$\begin{array}{lll}55.471 & 19 & .000\end{array}$

constrained equal

\section{Model 3 (Partial metric} invariance)

$\begin{array}{lllllllll}\text { All factor loadings } & 1356.746 & 606 & .041 & .96 & 3 \text { vs. } 1 & 20.677 & 13 & .110 \\ \text { constrained equal except } & & & & & & & & \\ \text { for BPrest2, CBSE4, } & & & & & & & & \\ \text { CAC2, ABC3, ABC4 } & & & & & & \end{array}$

Note: RMSEA $=$ Root mean squared error of approximation; CFI $=$ Comparative fit index; $\Delta \chi^{2}=$ Difference in chi-square values between models; $\Delta \mathrm{df}=$ Difference in number of degrees of freedom between models; BPrest $=$ Brand Prestige; $\mathrm{CBSE}=$ Community-based Self-esteem; $\mathrm{CAC}=$ Community Affective Commitment; $\mathrm{ABC}=$ Affective Brand Commitment 